\title{
Partial Replacement of Fine Aggregate in Concrete by Tyre Rubber
}

\author{
Jasmin M \\ Department of Civil Engineering \\ Musaliar College of Engineering \\ Thiruvananthapuram, India
}

\author{
Hafiz Hashimkutty \\ Department of Civil Engineering \\ Musaliar College of Engineering \\ Thiruvananthapuram, India
}

\begin{abstract}
Disposal of waste tyres is considered one of the major environmental challenges the world is facing because waste rubber is not easily biodegradable even after a long period of landfill treatment. One of the solutions suggested was the use of tyre rubber as partial replacement of fine aggregate in cement-based materials. An experimental program was carried out to investigate the compressive strength of concrete with shredded tyres as a fine aggregate in concrete .A number of cubes, prisms, cylinders were casted of M25 grade for this study. The replacement of aggregates with shredded tyres was partial in the concrete specimens according to the mix designs required in terms of weight and strength. The specimens were cured in water for required number of days before testing. Test results indicate clear substantial reduction in strength of the concrete when aggregate is replaced beyond $5 \%$ shredded tyres compared with the compressive strength of concrete with no shredded tyres.
\end{abstract}

Keywords-Concrete; replacement of fine aggregate ;scrap rubber;

\section{INTRODUCTION}

Utilization of scrap tyres should minimize environmental impact and maximize conservation of natural resources. One possible solution for this problem is to incorporate rubber particles into cement-based materials. Scrap tyres can be shredded into raw materials for use in hundreds of crumb rubber products. The other part of the problem is that aggregate production for construction purpose is continuously leading to the depletion of natural resources. Moreover, some countries are depending on imported aggregate and it is definitely very expensive. For example, the Netherlands does not possess its own aggregate and has to import. This concern leads to a highly growing interest for the use of alternative materials that can replace the natural aggregates. Therefore, the use of recycled waste tyres as an aggregate can provide the solution for two major problems: the environmental problem created by waste tyres and the depletion of natural resources by aggregate production consequently the shortage of natural aggregates in some countries.

According to the Automotive Tyre Manufacturers Association (ATMA), in India, more than 92.2 million tyres of various categories were manufactured in year 2012-13. Based on an estimate, $60 \%$ of the waste tyres are disposed off via unknown routs. The raw materials in tyres include natural and synthetic rubber, carbon black, nylon, polyester and even kevlar cord, sulfur, oils and resins, and other chemicals. Tyre rubber with fiber and steel belting comprise the major elements of tyres currently being used. Of all the possible methods of tyre disposal, the creation of rubber crumb potentially offers the most effective environmental solution, because this is the material that can be used in a variety of other products. Tyre rubber is ground to a particulate form termed as crumb rubber modifier (CRM) because its inclusion modifies properties of the asphaltic material. Crumb rubber consists of particles ranging in size from $4.75 \mathrm{~mm}$ (No. 4 Sieve) to less than $0.075 \mathrm{~mm}$ (No. 200 Sieve). The composition of CRM depends greatly upon the original chemistry of the tyre rubber and subsequent contamination during its use. Tyres can be used for environmentally safe applications in whole, cut, or stamped form in civil engineering works such as highway crash barriers, sound absorbing walls, boat benders on harbor walls as insulation in building foundations, and road base materials besides in Portland cement concrete system.

\section{LITERATURE REVIEW}

Recycled waste tyre rubber is a promising material in the construction industry due to its lightweight, elasticity, energy absorption, sound and heat insulating properties. The Literature available reveals that used rubber tyre can be effectively used in concrete to enhance the various properties of concrete and to protect environment. A mixture composed of ordinary concrete and rubber from the recycled tyres has been presented in technical literature under the name of "Rubber Concrete" or "Rubber Modified Concrete". The literature available also shows that workable rubberized concrete can be made with appropriate percentage of rubber tyre aggregates .

Sara Sgobba et al, (2010) .The study explores the ameliorative effects of rubber particles on some properties of concrete. The result presented shows that the incorporation of rubber aggregates in concrete, obtained from waste tyres, is a suitable solution to decrease the weight in some engineering manufactures. Some drawbacks were also reported by her such as the large decrease in compressive strengths, and the increase of water request and air content, the test result demonstrated that rubberized concrete mix possesses interesting properties that can be useful in structural and nonstructural applications. The test result also shows that the performance of concrete is significantly affected by the type and content of the rubber particles as well as by cement type and admixture properties.

El-Gammalet al, (2010) The application of recycled waste tyre rubber by replacing fine and coarse aggregate in concrete has been performed at different percentages to study the change in compressive strength $\&$ density of concrete. Two different forms of waste rubber tier have been used in the study. The result for the concrete casted using chipped rubber 
as a full replacement to coarse aggregate shows a significant reduction in the density (about $30 \%$ reduction) \& compressive strength (about $90 \%$ reduction) compared to controlled specimen. However significant ductility was observed before failure. The result obtained for the concrete casted using crumb rubber as a full replacement to sand shows significant reduction in compressive strength compared to controlled specimen but shows significant increase in compressive strength compared to the concrete casted using chipped rubber as a full replacement to coarse aggregate

Malek K. Batayneh et al, (2008).A research was carried out to find a positive method for disposing non-decaying materials, such as reuse in concrete mixes. Crumb rubber was used in the concrete mix to partially substitute for fine aggregate (sand) in various percentages of $20 \%, 40 \%, 60 \%$, $80 \%, 100 \%$. For each mix, cubes of $100 \times 100 \times 100 \mathrm{~mm}$, cylinders of $150 \mathrm{~mm}$ diameter by $300 \mathrm{~mm}$ height, and small beams of 100x100x400 mm were prepared. All specimens were fabricated and then cured in water for 28 days in accordance with ASTM/C192M-06 Standard practices. For each concrete mix, slump test were performed and recorded at the casting time of the specimens. After curing, specimens were tested for compressive strength, split tensile strength \& flexural strength in accordance with ASTM specified procedures. In his analysis he found that crumb rubber content in mix resulted in a decrease in both the slump \& unit weight of the mixtures. However mix still produced a workable mix in comparison with the control mix. He also reported the reduction in compressive strength, tensile strength $\&$ flexural strength (i.e. crumb rubber reduces all types of tested strength). On the basis of his analysis he concluded that higher the rubber content in the mix, the higher the reduction in compressive, tensile \& flexural strengths hence it is not recommended to use this modified concrete in structural elements where higher strength is required but it can be used in many other construction elements like partition walls, road barriers, pavements sidewalks, etc.

F. Hernadez-Olivares et al, (2002) According to his analysis the addition of crumb rubber tyre rubber volume fractions up to $5 \%$ in a cement matrix does not imply a significant variation on the concrete mechanical features, either maximum stresses or elastic modulus. The mechanical static test result for compressive, indirect tension (Brazilian method) \& four point bending strength on standard specimen with fibre reinforcement concrete at $7 \& 28$ days showed an admissible dispersion as compared to controlled mix. According to F. Hernadez-Olivares rubber fibre-filled specimens show larger result dispersions than sets without fibre, and Gauss distribution is wider in the first case than in the second. It means that Fibre-filled concrete is less reliable than controlled mix (without any fibre) and maximum compressive strength decreases slightly.

In dynamic compression test when a periodic compressive load was applied on the material, shows relaxation on rubber filled concrete. The strain effect appears delayed with regard to the moment when the load is applied. This delay on the deformation is a direct consequence of the internal nature of the material. Specimens with higher fibre volumetric fraction (5\%) dissipated more energy than lower contents of fibre (3.5\%). The high percentage of the specific energy dissipated (between $23 \%$ \& 30\%), which makes this material with high contents of recycled tyre rubber an optimal candidate for absorbing and dissipating energy under dynamic actions without damage.

\section{OBJECTIVES AND SCOPE OF THE STUDY}

\section{A. Objectives}

The specific objectives of this study are listed as follows:

- With the increase in urbanization, the number of cars and consequently the amount of used tyre is going to increase significantly in the near future. Hence, the non-environmental nature of these wastes is going to be a potential threat. This study can show an alternative way of recycling tyres by using them into concrete construction. Therefore, it is the aim of this study to introduce an environmental friendly technology, which can benefit the society and the nation. ."

- Application of used tyres in concrete construction is a new technology and a well-developed mix design for material proportioning is not available. Through this study, it is intended to arrive at a suitable mix proportion and percent replacement using locally available materials by partial replacement of the natural coarse aggregates with recycled coarse rubber aggregates. Hence the possibility of using waste tyres as an alternative construction material will be investigated.

- By conducting different laboratory tests on prepared specimens, it is intended to analyze the results.

\section{B. Scope of the study}

Though rubberized concrete has proven its applications in various construction fields, still a lot of research has to be done to measure the elastic constants and mechanical properties of rubberized concretes by adding rubber in different volume proportions, water-cement ratios, aspect ratios and in different forms such as fiber chips, powder form, etc. so that the appropriate strength can be explored. Here the study is conducted with varying percentage of scrap pieces of rubber in concrete viz 5\%, 10\%, $20 \%$.

\section{EXPERIMENTAL INVESTIGATIONS}

Various materials needed for the theses work were collected and their initial tests were performed. The details of the experimental investigation are given below.

\section{A. Workability Aspect}

For each mix the fresh property of concrete is ascertained using the slump test and compacting factor test. Different methods are available to check the workability of port land cement concrete.

The slump test is a means of assessing the consistency of fresh concrete. It is used, indirectly, as a means of checking that the correct amount of water has been added to the mix. The test is an empirical test that measures the workability of fresh concrete. More specifically, it measures consistency between batches. The test is popular due to the simplicity of 
apparatus used and simple procedure. The steel slump cone is placed on a solid, impermeable, level base and filled with the fresh concrete in three equal layers. Each layer is rodded 25 times to ensure compaction. The third layer is finished off level with the top of the cone. The cone is carefully lifted up, leaving a heap of concrete that settles or 'slumps' slightly. The upturned slump cone is placed on the base to act as a reference, and the difference in level between its top and the top of the concrete is measured and recorded to the nearest 5 $\mathrm{mm}$ to give the slump of the concrete.

The compaction factor test measures the degree of compaction resulting from the application of a standard amount of work. The test was developed in Britain in the late 1940s and has been standardized as British Standard 1881103. The test has typically been used in precast operations and at large construction sites. The specimens confirms the IS specification are selected. Compared to the slump test, the apparatus is bulky and a balance is required to perform measurements.

$$
\text { Compacting Factor }=\mathrm{W}_{\mathrm{p}} / \mathrm{W}_{\mathrm{f}}
$$

$\mathrm{W}_{\mathrm{p}}=$ weight of partially compacted concrete

$\mathrm{W}_{\mathrm{f}}=$ weight of fully compacted concrete

\section{B. Determination of hardened state properties}

Different tests were conducted in the laboratory to determine the mechanical properties such as compressive strength, split tensile strength, flexural strength of design mix and the partial replacement of fine aggregate by rubber in concrete mix. For determining the properties of hardened concrete the specimen sizes and number of specimens required for each test are given in Table I. All the specimens were tested after 7 and 28 days of curing.

TABLE I SIZE AND NUMBER OF SPECIMENS

\begin{tabular}{|c|l|c|c|c|}
\hline $\begin{array}{c}\text { Sl } \\
\text { no }\end{array}$ & \multicolumn{1}{|c|}{ Hardened properties } & Specimens & $\begin{array}{c}\text { Dimensio } \\
\text { ns }\end{array}$ & $\begin{array}{c}\text { No of } \\
\text { spec- } \\
\text { imens }\end{array}$ \\
\hline 1 & $\begin{array}{l}\text { Compressive } \\
\text { strength of concrete }\end{array}$ & Cubes & $\begin{array}{c}150 \mathrm{X} 150 \\
\mathrm{X} 150 \mathrm{~mm}\end{array}$ & 6 \\
\hline 2 & $\begin{array}{l}\text { Flexural strength of } \\
\text { concrete }\end{array}$ & Prisms & $\begin{array}{c}500 \mathrm{x} 100 \\
\mathrm{x} 100 \mathrm{~mm}\end{array}$ & 3 \\
\hline 3 & $\begin{array}{l}\text { Split tensile strength of } \\
\text { concrete }\end{array}$ & $\begin{array}{c}\text { Diameter } \\
: 150 \mathrm{~mm} \\
\text { Cylinders } \\
: 300 \mathrm{~mm}\end{array}$ & 3 \\
\hline
\end{tabular}

Compression test is the most common method conducted on hardened concrete partly because it is an easy test to perform, and partly because most of the desirable characteristics properties of concrete are qualitatively related to its compressive strength. Standard cubes of size $150 \mathrm{~mm}$ $\mathrm{x} 150 \mathrm{~mm} \times 150 \mathrm{~mm}$ are used. The capacity of testing machine is $1600 \mathrm{KN}$. The specimens are placed in the machine such that the load is applied to opposite sides of the casting face of the cubes. The rate of loading is $140 / \mathrm{cm}^{2} /$ minute. The maximum load applied to the specimen is recorded. The compressive strength $\mathrm{Fc}$ is found out from the given equation .

$$
\mathrm{Fc}=\mathrm{P} / \mathrm{A}
$$

Where,

$\mathrm{P}=$ Compressive load at failure $(\mathrm{N})$

$\mathrm{A}=$ Cross sectional area $\left(\mathrm{mm}^{2}\right)$

Similar to conventional concrete, rubber aggregate concrete is also relatively strong in compression and weak in tension. Standard prisms of size $100 \mathrm{~mm}$ x $100 \mathrm{~mm}$ x $500 \mathrm{~mm}$ are used to determine the flexural strength. The specimens are placed in the machine such that the load is applied to the top surface as cast in the mould along two lines spaced $13 \mathrm{~cm}$ apart. The axis of the specimen is carefully aligned with the axis of the loading device. The rate of loading is 180 $\mathrm{kg} /$ minute. The load is applied until the specimen failed and the maximum load applied to the specimen during the test is recorded. Flexural strength is determined from the equation given below.

Flexural strength or modulus of rupture ,

$$
\mathrm{F}_{\mathrm{b}}=\frac{P L}{\mathrm{~b} d^{2}} \geq 0.7 \sqrt{\mathrm{f}_{\mathrm{ck}}}
$$

Where, $\mathrm{P}=$ Flexural load $(\mathrm{N})$

$\mathrm{L}=$ Length of specimen $(\mathrm{mm})$

$\mathrm{b}=$ Width of specimen $(\mathrm{mm})$

$\mathrm{d}=$ Height of specimen $(\mathrm{mm})$

Split tensile test is carried out on cylindrical specimens of $150 \mathrm{~mm}$ diameter and $300 \mathrm{~mm}$ height. The test is carried as per IS 5816-1999.The test is carried out by placing a cylindrical specimen horizontally between the loading surfaces of a compression testing machine and the load is applied until failure of the cylinder, along the vertical diameter. In this test, the compressive load is applied along the opposite generators of a concrete cylinder placed with its axis horizontal between the platens of a compression testing machine of capacity $1000 \mathrm{KN}$. Due to the applied loading a fairly uniform tensile stress is induced over nearly two-third of the loaded diameter. The magnitude of splitting tensile stress ie, acting in a direction perpendicular to the line of action of applied compression is given by;

$$
\mathrm{T}_{\mathrm{SP}}=\frac{2 \mathrm{P}}{\pi \mathrm{DL}} \nless 1 / 10^{\text {th }} \text { of characteristic strength }
$$

Where,

$$
\begin{aligned}
& \mathrm{T}_{\mathrm{SP}}=\text { Split tensile strength } \\
& \mathrm{P}=\text { Tensile load at failure }(\mathrm{N}) \\
& \mathrm{D}=\text { Diameter }(\mathrm{mm}) \\
& \mathrm{L}=\text { Length of the specimen }(\mathrm{mm})
\end{aligned}
$$

\section{RESULTS AND DISCUSSION}

The percentage of fine aggregates was partially replaced by different percentage crumb rubber in normal concrete. The fresh and hardened properties of rubcrete and various tests were carried out to study the hardened properties, flexural behaviour and durability performance of rubcrete.

\section{A. Workability Aspect}

The workability characteristics obtained is discussed in Table II and Table III. 
TABLE II SLUMP CHARACTERISTICS

\begin{tabular}{|c|c|c|}
\hline \multicolumn{3}{|c|}{ Workability of Concrete In terms of Slump Value } \\
\hline $\begin{array}{c}\text { S1. } \\
\text { No: }\end{array}$ & Test Series & $\begin{array}{c}\text { Slump Value } \\
(\mathrm{mm})\end{array}$ \\
\hline 1 & $\begin{array}{c}\text { Normal } \\
\text { concrete }\end{array}$ & 80 \\
\hline 2 & $\begin{array}{c}\text { Rubberised concrete } \\
(5 \%)\end{array}$ & 50 \\
\hline 3 & $\begin{array}{c}\text { Rubberised concrete } \\
(10 \%)\end{array}$ \\
\hline 4 & $\begin{array}{c}\text { Rubberised concrete } \\
(20 \%)\end{array}$ \\
\hline
\end{tabular}

TABLE III COMPACTING FACTOR TEST RESULTS

\begin{tabular}{|c|c|c|}
\hline \multicolumn{2}{|c|}{ Workability of Concrete In terms of Compacting Factor } \\
\hline $\begin{array}{c}\text { S1. } \\
\text { No: }\end{array}$ & Test Series & Compacting Factor \\
\hline 1 & $\begin{array}{c}\text { Normal } \\
\text { concrete }\end{array}$ & 0.963 \\
\hline 2 & $\begin{array}{c}\text { Rubberised concrete } \\
(5 \%)\end{array}$ & 0.978 \\
\hline 3 & $\begin{array}{c}\text { Rubberised concrete } \\
(10 \%)\end{array}$ \\
\hline 4 & $\begin{array}{c}\text { Rubberised concrete } \\
(20 \%)\end{array}$ & 0.88 \\
\hline
\end{tabular}

From the details obtained from the above tables, at $5 \%$ partial replacement of fine aggregate by crumb rubber, the workability is greater than that of normal concrete. When the crumb rubber content is increased there is a reduction in slump value and compacting factor respectively. Graphical representation of this trends are shown in Fig.1 and Fig.2 respectively.

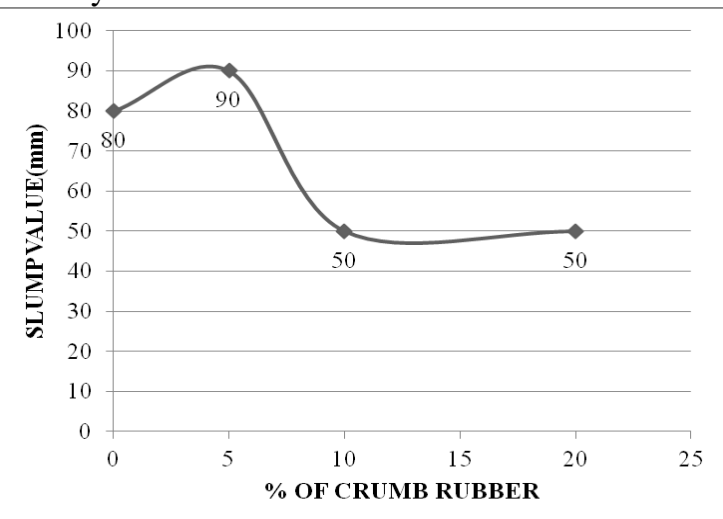

Fig. 1 Variation of Slump Value V/S Percentage of Crumb Rubber

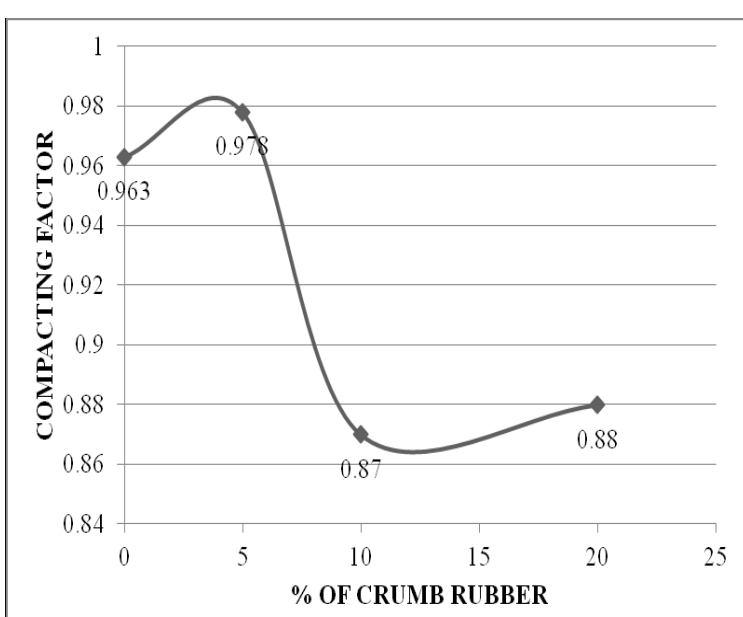

Fig.2 Variation of Compacting Factor V/S Percentage of Crumb Rubber

B. Hardened State Properties

Various tests to evaluate the hardened state properties of concrete at different levels of partial replacement of fine aggregate by crumb rubber were performed. The results obtained are discussed in the following tables

TABLE IV 7 DAYS COMPRESSIVE STRENGTH TEST

\begin{tabular}{|c|c|c|c|c|}
\hline \multicolumn{5}{|c|}{7 Days Test } \\
\hline$\%$ of Rubber & $\begin{array}{c}\text { Specimen } \\
\text { No: }\end{array}$ & $\begin{array}{l}\text { Maximum } \\
\text { Load Applied } \\
(\mathrm{kN} / \mathrm{min})\end{array}$ & $\begin{array}{c}\text { Compressive } \\
\text { Strength } \\
\left(\mathrm{N} / \mathrm{mm}^{2}\right)\end{array}$ & $\begin{array}{c}\text { Average } \\
\text { Compressive } \\
\text { Strength } \\
\left(\mathrm{N} / \mathrm{mm}^{2}\right)\end{array}$ \\
\hline \multirow{3}{*}{0} & 1 & 445 & 19.77 & \multirow{3}{*}{19.18} \\
\hline & 2 & 455 & 20.22 & \\
\hline & 3 & 395 & 17.55 & \\
\hline \multirow{3}{*}{5} & 1 & 565 & 25.11 & \multirow{3}{*}{23.7} \\
\hline & 2 & 525 & 23.33 & \\
\hline & 3 & 510 & 22.667 & \\
\hline \multirow{3}{*}{10} & 1 & 250 & 11.11 & \multirow{3}{*}{11.7} \\
\hline & 2 & 255 & 11.33 & \\
\hline & 3 & 285 & 12.667 & \\
\hline \multirow{3}{*}{20} & 1 & 210 & 9.33 & \multirow{3}{*}{10.221} \\
\hline & 2 & 230 & 10.22 & \\
\hline & 3 & 250 & 11.11 & \\
\hline
\end{tabular}

TABLE V. 28 DAYS COMPRESSIVE STRENGTH TEST

\begin{tabular}{|c|c|c|c|c|}
\hline \multicolumn{5}{|c|}{28 Days Test } \\
\hline$\%$ of Rubber & $\begin{array}{c}\text { Specimen } \\
\text { No: }\end{array}$ & $\begin{array}{l}\text { Maximum } \\
\text { Load Applied } \\
(\mathrm{kN} / \mathrm{min})\end{array}$ & $\begin{array}{c}\text { Compressive } \\
\text { Strength } \\
\left(\mathrm{N} / \mathrm{mm}^{2}\right)\end{array}$ & $\begin{array}{c}\text { Average } \\
\text { Compressive } \\
\text { Strength } \\
\left(\mathrm{N} / \mathrm{mm}^{2}\right)\end{array}$ \\
\hline \multirow{3}{*}{0} & 1 & 530 & 23.55 & \multirow{3}{*}{24.589} \\
\hline & 2 & 510 & 22.667 & \\
\hline & 3 & 620 & 27.55 & \\
\hline \multirow{3}{*}{5} & 1 & 630 & 28 & \multirow{3}{*}{29.033} \\
\hline & 2 & 650 & 28.88 & \\
\hline & 3 & 680 & 30.22 & \\
\hline \multirow{3}{*}{10} & 1 & 440 & 19.55 & \multirow{3}{*}{21.55} \\
\hline & 2 & 470 & 20.88 & \\
\hline & 3 & 545 & 24.22 & \\
\hline \multirow{3}{*}{20} & 1 & 240 & 10.667 & \multirow{3}{*}{13.849} \\
\hline & 2 & 355 & 15.77 & \\
\hline & 3 & 340 & 15.11 & \\
\hline
\end{tabular}




\begin{tabular}{|c|c|c|c|c|}
\hline \multicolumn{5}{|c|}{28 Days Test } \\
\hline$\%$ of Rubber & $\begin{array}{l}\text { Specimen } \\
\text { No: }\end{array}$ & $\begin{array}{l}\text { Maximum } \\
\text { Load Applied } \\
\text { (kN/min) }\end{array}$ & $\begin{array}{l}\text { Flexural } \\
\text { Strength } \\
\left(\mathrm{N} / \mathrm{mm}^{2}\right)\end{array}$ & $\begin{array}{c}\text { Average } \\
\text { Flexural Strength } \\
\left(\mathrm{N} / \mathrm{mm}^{2}\right)\end{array}$ \\
\hline \multirow{3}{*}{0} & 1 & 11 & 4.4 & \multirow{3}{*}{4.8} \\
\hline & 2 & 10.5 & 4.2 & \\
\hline & 3 & 14.5 & 5.8 & \\
\hline \multirow{3}{*}{5} & 1 & 11.5 & 4.6 & \multirow{3}{*}{4.33} \\
\hline & 2 & 11.5 & 4.6 & \\
\hline & 3 & 9.5 & 3.8 & \\
\hline \multirow{3}{*}{10} & 1 & 8.5 & 3.4 & \multirow{3}{*}{3.8} \\
\hline & 2 & 11.5 & 4.6 & \\
\hline & 3 & 8.5 & 3.4 & \\
\hline \multirow{3}{*}{20} & 1 & 2.5 & 1 & \multirow{3}{*}{1.333} \\
\hline & 2 & 3.5 & 1.4 & \\
\hline & 3 & 4 & 1.6 & \\
\hline
\end{tabular}

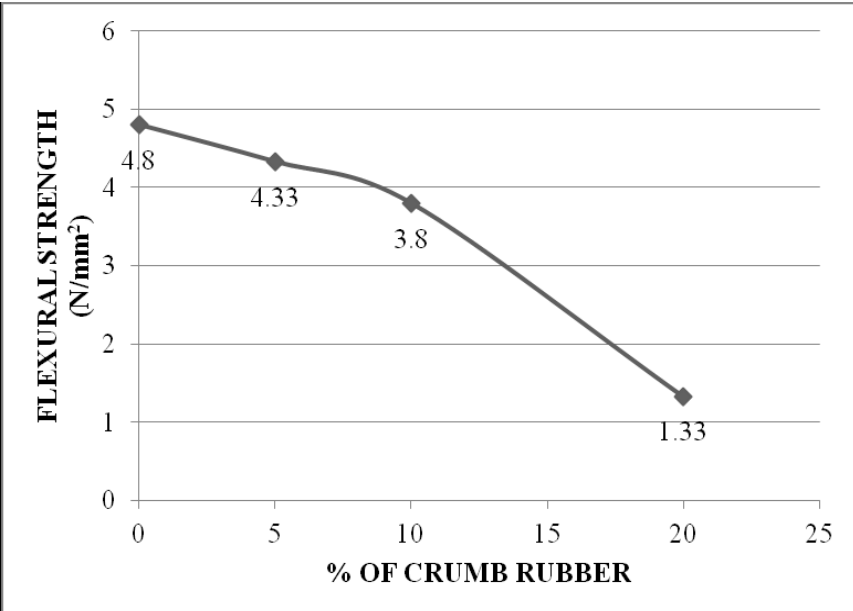

Fig.4 Variation of 28 Day Flexural Strength v/s Percentage of Crumb Rubber

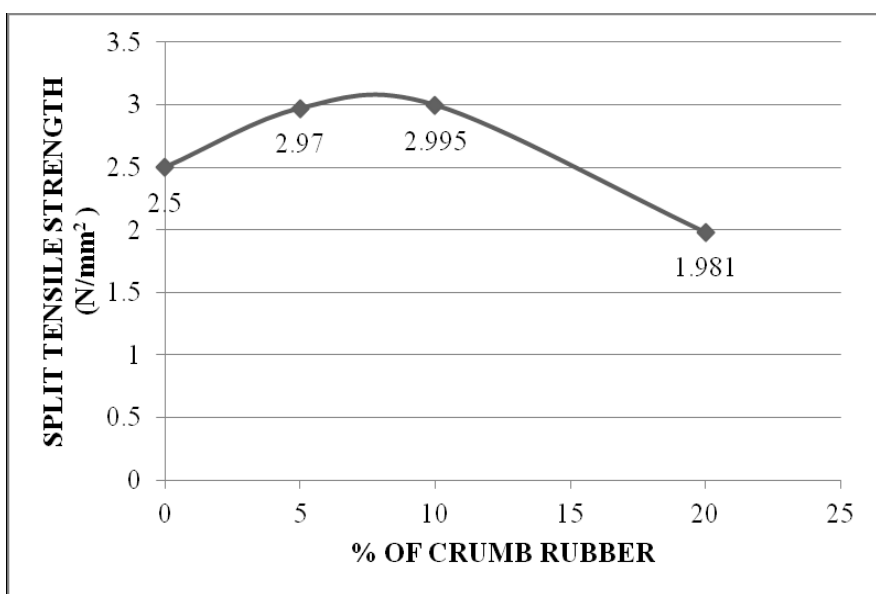

Fig.5 Variation of 28 Day Split Tensile Strength v/s Percentage of Crumb Rubber

\section{CONCLUSIONS AND FUTURE SCOPE}

This study represents the effect of waste tyre crumb rubber particle of size passing through $4.75 \mathrm{~mm}$ IS sieve used in concrete on compressive, flexural and split tensile strength. From the results obtained during investigation following conclusions can be drawn:

- $5 \%$ replacement of crumb rubber has more workability, strength in compression and tensile strength than the regular M25 concrete.

- $5 \%$ replacement of crumb rubber has low flexural strength than normal concrete but it confirms the IS specification hence it can be used construction purpose.

- For rubberized concrete, the test results show that the addition of rubber aggregate more than $5 \%$ will result in a reduction in concrete compressive strength compared with the normal concrete. This reduction increased with increasing percentage of rubber aggregate. Losses in compressive strength are observed. The reason for the strength reduction is due to lack of adhesion at the boundaries of the rubber aggregate, soft rubber particles behave as voids in the concrete matrix. 
- Rubberized concrete showed ability to absorb a large amount of plastic energy and did not show brittle failure under compression or split tension loading.

- The results of the splitting tensile strength tests show that, there is a decrease in strength with increasing rubber aggregate content as reduction observed in the compressive strength tests. However, there was a smaller reduction in splitting tensile strength as compared to the reduction in the compressive strength.

- Higher content of waste tyre crumb rubber produces light weight concrete.

- Higher content of waste tyre crumb rubber particle shows higher to medium workability.

- Because of the long term performance of these mixes are not known in the field, especially for pavement sections, the use of such mixes are recommended in places where high strength of concrete is not as important (e.g. sidewalls).

- There is a potential large market for concrete products in which inclusion of rubber aggregates would be feasible which will utilize the discarded rubber tyres the disposal of which is a big problem for environment pollution.

- The existence of any chemical reactions between the rubber aggregate and other constituents of the rubberized concrete to make sure that there is no undesirable effects that are similar to alkali-silica and alkali-carbonate reactions in natural aggregates needs to be investigated.

- This research was done by preparing single graded rubber aggregates of size $4.75 \mathrm{~mm}$. The effect of different sizes should be studied in the future. Besides to this, the effects in different percentage replacements other than those made in this research needs to be investigated.
Further investigation is necessary to improve the hardened properties of rubber filled concrete, to gain the loss strength due to the use of waste tyre crumb rubber at higher content in concrete mix. The use of crumb rubber in concrete mix is very much beneficial to environmental concern and to solve the problem related to disposal of waste tyre rubber throughout the world. Most of the time, it is observed that designers and contractors go to a high strength and expensive concrete to get few improved properties such as impact resistance in parking areas and light weight structures for applications. Nevertheless, these properties can be achieved through the application of rubberized concrete by first conducting laboratory tests regarding the desired properties. Therefore, the use of rubberized concrete as an alternative concrete making material needs an attention.

\section{REFERENCES}

[1] Batayneh, M.K., I. Marie, and I. Asi, "Promoting the use of crumb rubber concrete in developing countries". Waste Management, 2008 28(11): p. 2171-2176)

[2] Eldin N.N. \& Senouci A.B. - "Rubber tire particles as concrete aggregates", ASCE Journal of materials in Civil Engineering, 1993, 5(4), 478-496.

[3] Huang, B., et al., "Investigation into waste tire rubber-filled concrete."Journal of Materials in Civil Engineering, 2004. 16 p. $187-$ 194.

[4] IS: 383-1970- "Specifications for coarse and fine aggregates from natural sources for concrete" (Second revision) BIS, New Delhi.

[5] Li, G., et al.," Development of waste tire modified concrete". Cement and Concrete Research, 2004. 34(12): p. 2283-2289.

[6] Nehdi Moncef And Khan Ashfaq- "Cementitious Composites Containing Tire Rubber" Cement, Concrete and Aggregate Vol. 23 No. 1 June 2001. Pp 3-10.

[7] Rakesh Kumar and Tarun R. Naik "Greener concrete using postconsumer products" The Indian Concrete Journal April 2014, Volume 88, Number 4 Page No 16

[8] Siddique, R. And T.R. Naik, "Properties of concrete containing scraptire rubber--an overview." Waste Manag, 2004. 24(6): p. 563-9.

[9] Topeu I.B. "The properties of rubberized concrete" cement and concrete research 1995, 25(2), 304-310

[10] ASTM International Standards, http: // www.astm.org/standards,2009. 